ÉGYPTE

monde arabe

\section{Égypte/Monde arabe}

$21 \mid 1995$

Économie égyptienne et perspectives de paix au Proche-Orient

\title{
Structural Reform in Egypt
}

Milan Zavajil

\section{(2) OpenEdition}

Journals

Electronic version

URL: https://journals.openedition.org/ema/392

DOI: 10.4000/ema.392

ISSN: 2090-7273

Publisher

CEDEJ - Centre d'études et de documentation économiques juridiques et sociales

\section{Printed version}

Date of publication: 31 March 1995

Number of pages: 143-146

ISSN: 1110-5097

\section{Electronic reference}

Milan Zavajil, "Structural Reform in Egypt", Égypte/Monde arabe [Online], 21 | 1995, Online since 08 July 2008, connection on 07 July 2022. URL: http://journals.openedition.org/ema/392 ; DOI: https:// doi.org/10.4000/ema.392

This text was automatically generated on 7 July 2022 .

All rights reserved 


\title{
Structural Reform in Egypt
}

\author{
Milan Zavajil
}

1 Thank you for inviting me to open today's round table discussion on the subject of Egypt's economic reform program. At this important juncture of the reform process, when the Government is placing greater emphasis on structural reform supported by prudent macroeconomic policies, we welcome the convening of this round table. It is an excellent opportunity for a candid exchange of opinion among government officials, the academic community, and representatives of multilateral institutions on the results of three years of economic reform, and on the outlook for the period ahead.

2 The note prepared by Ms. Clément provides a good background for the discussion. In my remarks I will follow broadly the outline proposed by her, focusing primarily on (i) the macroeconomic policies implemented under the reform program, (ii) an assessment of economic performance since early 1991 and (iii) the outlook for the next few years, including a discussion of policies that are expected to be implemented. I hope that my statement provides a factual groundwork and would facilitate the subsequent discussion.

3 The achievements of Egypt's reform program should be assessed taking into account the nature and state of the economy in the late 1980s. Economic growth for over three decades had been generated primarily by an extensive public investment program; the public sector dominated almost all sectors of the economy. Despite generous foreign financing, which resulted in a rising debt burden, domestic bank borrowing was increasingly required to cover fiscal deficits, and was reflected in the build-up of inflationary and balance of payments pressures. These pressures were partially suppressed through trade, foreign exchange, and price controls, causing distortions that reduced the efficiency of investment, hindered the development of the traded goods sector, and stuck private sector activity; in the event, the pressures were manifested most clearly in the accumulation of external arrears. Moreover, in the late 1980 s the inflation rate rose to a peak of 30 percent in spite of comprehensive price controls and economic growth slowed to near stagnation as the Government curtailed public investment in the face of reduced external resources. 
Initial efforts at economic reform were initiated in the late 1980s, and an integrated and coherent program of economic reform started to be implemented in early 1991 . The economic program involved intensified macroeconomic stabilization and broadbased and far-reaching structural reform policies. It was supported by a two year stand-by arrangement from the International Monetary Fund, a World Bank Structural Adjustment Loan, and debt cancellation and relief from Paris Club and other official bilateral creditors, as well as increased direct assistance from many countries.

Bold macroeconomic stabilization measures were implemented at the outset of the program. Regarding fiscal policy, government revenue was enhanced by improved administration and collection, the introduction of a global sales tax, and substantial increases in domestic energy prices toward international levels. As a result, the ratio of revenues to GDP rose from 25 percent in 1989/90 to a projected 35-36 percent in $1993 / 94^{1}$. Public sector investment was reduced from 12 percent of GDP to 7 percent during thy same period, and had increasingly focused on infrastructure and social services, while leaving areas such as manufacturing and telecommunications to the private sector. The broad array of subsidies evident in earlier years has been greatly curtailed; the only major subsidy that will remain soon will be on popular bread. However, efforts to control the Government wage bill have been only partially successful as employment has continued to grow, despite initiatives to prevent the Government from being "the employer of last resort". As a result of these actions, the overall fiscal deficit has shrunk from 15.8 percent of GDP in 1989/90 to a programmed 2.6 percent in 1993/94.

6 The reduced Government bank borrowing, together with the generally prudent credit stance, has limited monetary expansion and facilitated the implementation of financial reforms. Most importantly, deposit and lending interest rates have been liberalized, and are now determined on the basis of supply and demand. In addition, ceilings on lending by individual banks have been abolished, and monetary conditions are now regulated through Treasury bills auctions. Bank supervision has been strengthened with the introduction of international standards for loan classification and provisioning, limits on lending and foreign currency exposure, and audits of the public banks.

7 After decades of comprehensive controls and the existence of a fragmented market and multiple exchange rates, a free market foreign exchange System with a unified rate was introduced in 1991. The private sector was permitted to purchase foreign exchange freely from banks and foreign exchange dealers, which greatly helped to enhance confidence; and restrictions on the operations of the dealers have been gradually eased.

8 Some progress has also been made in implementing structural reforms. In the foreign trade area, the coverage of import bans has been reduced to only 5 percent of domestic production, compared with 40 percent in 1989; and tariff protection has also been reduced significantly, though it still remains high by international standards. Most domestic prices have been liberalized, though a few important exemptions remain. Public enterprise restructuring and privatization has also begun. The above policies have contributed to a significant improvement in economic performance. Inflation has dropped gradually to just over 7 percent per annum in early 1994, the lowest rate in twenty years, although it is still higher than inflation in major trading partners. The overall balance of payments has shifted from a deficit in 1990/91 to surpluses averaging about US $\$ 4$ billion in the subsequent three years. The outcome reflects in particular 
migrant workers' remittances and substantial inflows of private capital attracted by open financial markets and by high relative returns on Egyptian pound denominated assets, but also depressed imports. Net international reserves, which were practically exhausted by the end of $1989 / 90$, have risen to over US $\$ 16$ billion currently, equivalent to almost a year and a half of imports. The strengthening of the external position, which now provides a solid foundation to intensify the reform effort, is probably the most important achievement of the reform program thus far. Over the past three years, however, economic growth has not exceeded 1 percent per annum, and non-oil exports has substantially contracted. Furthermore, investment has been stagnating. Thus, overall, it appears that the private sector has not yet started to respond to the more stable macroeconomic environment and the incentives provided by the structural reforms that have been implemented so far, which comes somewhat as a surprise. This begs the question as to whether this weak response from the private sector reflects the fact that a critical mass of structural measures has in fact not yet been effectively implemented or whether delays in implementing some of the envisaged key structural reforms might have reinforced a "wait-and-see" attitude on the part of the private sector.

9 In the current phase of the reform program, the key objective of the Egyptian authorities is to attain a higher and sustainable rate of economic growth and improved employment opportunities. To this end, the structural reforms are to be broaden and deepened, while ensuring the continuing viability of the balance of payments and further reducing inflation to partner country levels. These goals are to be achieved through the timely implementation of a comprehensive economic and financial reform program, which was put in place last summer, and is supported by a three-year extended arrangement from the IMF and a structural adjustment monitoring program by the World Bank.

10 What kind of economic performance can be expected over the next few years? In view of the continuing uncertainty over the private sector's response to the reforms, economic growth is projected lo accelerate but only gradually, from an estimated 2 percent per annum in 1993/94 to over 5 percent in 1996/97. Given the increased mobility of domestic and foreign capital, however, such an acceleration in the rate of growth can only be achieved through determined implementation of policies to trigger an improvement in the overall investment environment in Egypt relative to that in other countries both inside and outside the region. Inflation is projected to be reduced from an average of 9.5 percent in 1993/94 to about 4 percent by 1996/97. The overall balance of payments surplus is expected to diminish gradually to about US $\$ 1$ billion in 1996/97, reflecting mainly smaller current account surpluses caused to a large extent by expected stronger import growth. The latter, particularly ol capital goods and equipment and key industrial inputs, is to underpin the medium-term growth objective through enhanced investment in productive and job-creating activities.

11 To achieve the objectives of the current economic program, the authorities need to make further progress in macroeconomic stabilization, as well as to intensify tax, regulatory, trade, and public enterprise reform. Consolidation of the progress made so far in financial reform is also needed.

12 Continued progress in macroeconomic stabilization is needed to reduce inflation and maintain confidence in balance of payments viability, both of which are vital for private sector confidence. Indeed, with free money, capital, and foreign exchange 
markets, and the increased size of private capital flows with their sensitivity to relative yields, sound macroeconomic policies are now more essential than ever: Most importantly, the further strengthening of the fiscal position is crucial to reduce interest rates and allow resources to shift to the private sector. Lower interest rates will also help to dampen private capital inflows, the sterilization of which through the issue of Treasury bills has had a heavy budgetary cost in recent years. It should be noted that while interest rates have declined considerably over the past six months, they remain quite high in real terms, particularly in view of the recent decrease in inflation.

The objectives of tax policy under the program are to shift the burden of taxation from international trade to income and consumption, while improving the efficiency and equity of the tax System, the global income tax law recently approved by the People's Assembly provides for taxation of most income according to a single schedule, which will reduce some of the distortions arising under the previous system. The reduction of top marginal personal income tax rates should improve incentives while higher personal exemptions and tax thresholds will remove many families taxpayers from the tax rolls. The introduction of a value-added tax, which has been announced by Minister Razaz for July 1995, will also enhance efficiency, as well as reducing the tax burden of many producers. However, certain tax issues remain to be tackled, including a reduction of corporate tax exemptions and expanding taxation to sources of income currently not taxed. The complicated stamp tax system, which is expensive to administer, also needs to be reviewed. Regarding the regulatory environment, some progress has been made towards removing bureaucratic obstacles to private sector investment. A number of other measures will be forthcoming, the most important of which will be the introduction of a new companies law that is expected to further facilitate the establishment of new enterprises, and rationalize the legal framework under which companies operate.

Building on the progress made over the last three years, a number of steps to reduce and rationalize customs tariffs, as well as to remove remaining non-tariff barriers, are envisaged by the authorities; Most importantly, the maximum tariff will be reduced in two steps from the current 70 percent to 50 percent by mid-1995, with a reduced number of exemptions. All tariffs of over 30 percent will be reduced in parallel with the maximum tariff, with tariffs on ail capital goods imports being reduced to 5 percent or 10 percent in order to encourage investment. Practically all non-tariff barriers are to be removed by mid-1994 and the system of import quality controls is to be harmonized with international standards. These measures are essential to promote competition and improve productivity in the Egyptian economy. A more rapid pace of tariff reduction could only enhance these processes.

Privatization and public sector restructuring have in recent months been subject to more discussion on the Egyptian economic scene than any other issue. A faster pace of privatization would contribute to the more efficient use of privatized resources and widen the scope for private sector activity. It could also, given the prominence of the issue, strengthen private sector confidence in the reform program as a whole, and thus encourage investment the representative of the World Bank will comment more comprehensively on this issue.

17 Finally, a word on the outlook for financial reform, as requested by Ms. Clément. While some important tasks remain, most of the major banking System reforms have been 
completed, as discussed above. Nevertheless, the authorities intend to continue to enhance competition in the banking system through the sale of the Government share in joint venture banks and, eventually, the privatization of a public bank. Efforts to improve prudential supervision will be continued, and the authorities will take every opportunity to reduce bank reserve requirements to lower the cost of financial intermediation, subject to liquidity conditions. In addition, the Government sees the development of the currently rather dormant securities market as an important element in establishing a market-based economy, particularly as recent offerings have triggered considerable interest among the Egyptian public for shares. Comprehensive steps are being taken to strengthen institutionally and technologically the securities markets, which will be discussed by the World Bank representative. These measures should also facilitate the privatization process.

It should also be noted that the authorities are undertaking efforts to. cushion the transitional social costs of the reform process- the Social Fund for Development appears to have accelerated the pace of its commitments, though disbursements remain small; in compensating and retraining dislocated workers, the Social Fund can provide valuable support for the public enterprise reforms. the authorities are also developing a capacity to target subsidies to the poorest segments of the population, and are striving lo increase the share of health and education in government current expenditure.

To summarize, as a result of the authorities resolve in implementing fiscal, monetary, and external policies at the outset of the reform process over the past three years, the external position has strengthened noticeably and the rate of inflation has started to decline, providing thereby a strong base for further reform. Some progress has also been made with regard to structural reform, but so far the private sector has remained reluctant to increase investment substantially, and economic growth remains modest.

This problem can be effectively addressed only by deepening and broadening the structural reforms, while continuing to strengthen macroeconomic policies. Such an approach is the key to boosting business confidence and thus stimulating private sector investment, which is needed to general growth and employment opportunities.

\section{NOTES}

1. Fiscal year starting July. 
INDEX

Mots-clés: réforme structurelle

\section{AUTHOR}

MILAN ZAVAJIL

IMF Resident Representative 